\title{
Artikel
}

\section{Toerekening van kennis van een gevolmachtigde - een verkenning van artikel 3:66 lid 2 BW}

\section{Inleiding}

Gevolmachtigde $G$ koopt op verzoek van volmachtgever $\mathrm{V}$ een antieke kast. De kast blijkt na aankoop echter helemaal niet antiek. Kan V zich jegens wederpartij W beroepen op dwaling? Als voor een deskundige direct zichtbaar was dat de kast niet antiek was en G op dit gebied deskundig was, dan zal $\mathrm{V}$ zich niet kunnen beroepen op dwaling: in de relatie tussen $\mathrm{V}$ en $\mathrm{W}$ wordt de (veronderstelde) kennis van $\mathrm{G}$ aan $\mathrm{V}$ toegerekend. Was $\mathrm{G}$ niet deskundig, maar $\mathrm{V}$ wel, en heeft $\mathrm{V}$ na een eerdere bezichtiging aan $\mathrm{G}$ specifiek de opdracht verstrekt om déze kast te kopen, dan komt $\mathrm{V}$ evenmin een beroep op dwaling toe: hij kan zich niet achter zijn onwetende gevolmachtigde verschuilen. Heeft $\mathrm{V}$ zich echter niet bemoeid met de keuze van de kast die de ondeskundige $\mathrm{G}$ zou gaan kopen, dan heeft $\mathrm{V}$ wel degelijk gedwaald, ook al had $\mathrm{V}$ de kast direct als een reproductie herkend. Dat is, in essentie, hoe artikel 3:66 lid 2 van het Burgerlijk Wetboek (BW) werkt. ${ }^{1}$

Wat een partij weet, is relevant voor de toepassing van veel leerstukken in het burgerlijk recht: van dwaling tot de actio pauliana, van bescherming van de derde te goeder trouw tot het onrechtmatig profiteren van wanprestatie. Rechtens relevante handelingen komen vaak tot stand door inschakeling van derden, zoals tussenpersonen, vertegenwoordigers en ondergeschikten. Op de vraag wanneer de kennis van zo'n derde kan worden toegerekend an degene ten behoeve van wie hij heeft gehandeld, geeft het Burgerlijk Wetboek echter nauwelijks concreet antwoord. Uitzondering daarop is de toerekening van de kennis van de gevolmachtigde aan de volmachtgever. ${ }^{2}$ Op grond van artikel 3:66 lid $2 \mathrm{BW}$ komen, voor zover het al of niet aanwezig zijn van een wil of van wilsgebreken, bekendheid of onbekendheid met feiten van belang is voor de geldigheid of de gevolgen van een rechtshandeling, ter beoordeling daarvan de volmachtgever of de gevolmachtigde of beiden in aanmerking, al naar gelang het aandeel dat ieder van hen heeft gehad in de totstandkoming van de rechtshandeling en in de bepaling van haar inhoud. Deze regel staat wel bekend als de leer van het grootste aandeel. Artikel 3:66 lid 2 BW lijkt niet veel bekendheid te genieten: er is weinig over gepubliceerd en in de rechtspraak wordt het maar zelden genoemd. ${ }^{3}$ De in dit artikellid vervatte regel wordt wel geregeld impliciet toegepast - alleen lang niet

* Mr. B.M. Katan is advocaat bij Stibbe en schrijft aan de Radboud Universiteit een proefschrift over de toerekening van kennis aan rechtspersonen. Reacties zijn welkom op.

1. Aankoop van een antiek voorwerp is het schoolvoorbeeld van de toepassing van art. 3:66 lid 2 BW. Zie A.R. Bloembergen, Vertegenwoordiging, Alpen aan den Rijn: Samson H.D. Tjeenk Willink 1988, p. 40; Asser/Van der Grinten \& Kortmann 2-I 2004/81; A.C. van Schaick, Volmacht, Monografieën BW B5, Deventer: Kluwer 2011, 41. geldt als kennis van de aannemer) en art. 7:928 lid 2 BW (kennis van de derde-verzekerde wordt toegerekend aan de verzekeringnemer).

3. Een uitzondering is HR 23 januari 1998, NJ 1999/97 (Jans/FCN), r.o. 3.4.2. Een beslissing over de toepassing van art. 3:66 lid 2 BW wordt in dat arrest - dat samenhangende overeenkomsten betreft - echter niet gegeven. Ook HR 4 mei 2001, S\&S 2002/13 (Bumblebee/Nieuw Rotterdam) betreft art. 3:66 lid 2 BW, maar behelst niet meer dan de sanctionering van de toepassing hiervan door het hof in een standaardgeval. 
altijd op de juiste manier. Voldoende reden dus voor een analyse van de werking van artikel 3:66 lid 2 BW.

In deze bijdrage behandel ik de volgende vragen:

1. Wat is een 'aandeel in de totstandkoming van de rechtshandeling en in de bepaling van de haar inhoud'?

2. Kan op basis van artikel 3:66 lid $2 \mathrm{BW}$, naast een wil en feitenkennis, ook deskundigheid worden toegerekend?

3. Wiens kennis geldt als de kennis van de volmachtgever indien de volmachtgever een rechtspersoon is?

4. Geldt artikel 3:66 lid 2 BW ook voor de verhouding tussen gevolmachtigden onderling en bij ondervolmacht?

5. In hoeverre is artikel 3:66 lid $2 \mathrm{BW}$ van toepassing op de rechtsverhouding tussen de volmachtgever en een ander dan zijn wederpartij?

6. Kan op basis van artikel 3:66 lid 2 BW ook in omgekeerde richting worden toegerekend, zodat de kennis van de volmachtgever geldt als die van de gevolmachtigde?

In het hierna volgende hanteer ik steeds de term 'gevolmachtigde'. Hoewel artikel 3:66 lid $2 \mathrm{BW}$ niet wordt genoemd in schakelbepaling 3:78 $\mathrm{BW}$, gaan de meeste schrijvers ervan uit dat ook de kennis van andere vertegenwoordigers, zoals wettelijke vertegenwoordigers, op deze voet kan worden toegerekend aan de vertegenwoordigde. ${ }^{4}$

\section{De leer van het grootste aandeel}

De formulering van artikel 3:66 lid $2 \mathrm{BW}$ roept vragen op. Letterlijk opgevat kan 'al naar gelang' ieders aandeel zo worden gelezen dat de kennis van de gevolmachtigde in aanmerking moet worden genomen naar rato van diens aandeel - alsof je bijvoorbeeld $25 \%$ van iemands kennis zou kunnen toerekenen. Uit de wetsgeschiedenis kan worden afgeleid dat de tekst niet zo letterlijk genomen moet worden: met 'het aandeel' wordt gedoeld op de invloed die volmachtgever en gevolmachtigde konden uitoefenen op het al dan niet tot stand komen van de rechtshandeling. ${ }^{5}$ Het lijkt neer te komen op de vuistregel: had de gevolmachtigde of volmachtgever op de totstandkoming en inhoud van de rechtshandeling geen of vrijwel geen invloed, dan hoeft diens kennis niet in aanmerking te worden genomen. Minimaal vereist is naar mijn mening dat de gevolmachtigde of de volmachtgever een reële mogelijkheid had om te voorkomen dat de rechtshandeling (op deze wijze) zou worden

4. A.G. Castermans, De mededelingsplicht in de onderhandelingsfase (diss Leiden), Deventer: Kluwer 1992, p. 78; R.P.J.L. Tjittes, Toerekening van kennis (lezing Studiekring Offerhaus), Deventer: Kluwer 2001, p. 14; Asser/Van der Grinten \& Kortmann 2-I 2004/82; Asser/Tjong Tjin Tai 7-IV* 2009/219; Van Schaick 2011, 72; J.J. Valk, Toerekening van externe kennis: twee gezichtspunten, WPNR (2012) 6949, p. 766-767. Zie ook PG Boek 3, p. 253 en p. 304.

5. PG Boek 3, p. 274. Zie ook Tjittes 2001, p. 15 verricht. ${ }^{6}$ 'Aandeel' moet dus niet kwantitatief worden opgevat.

Het begrip 'aandeel' kan wel kwalitatief worden opgevat, dat wil zeggen: het aandeel van de gevolmachtigde kan betrekking hebben op onderwerpen van een bepaalde aard. Stel dat een vertegenwoordiger met een specifieke expertise wordt ingezet om een bepaald technisch aspect in het contract uit te onderhandelen. Artikel 3:66 lid 2 BW leidt er dan mijns inziens toe dat de kennis en deskundigheid van deze gevolmachtigde aan de volmachtgever worden toegerekend ten aanzien van dit technische aspect, maar niet ten aanzien van aspecten waarmee de gevolmachtigde geen bemoeienis had. Stel dat er een geschil tussen de contractspartijen bestaat over de betekenis van een term in de overeenkomst, bijvoorbeeld 'belastingschade'. Indien de technisch expert van vertegenwoordigers van de wederpartij heeft opgevangen wat die onder 'belastingschade' verstonden, mag niet zomaar worden geconcludeerd dat ook de partij voor wie de technicus optrad dit wist.

Vanuit wiens perspectief moet worden bezien hoe groot de aandelen van volmachtgever en gevolmachtigde zijn? Volgens de Toelichting-Meijers draait het om de vraag of de gevolmachtigde met een zekere vrijheid naar eigen oordeel kon handelen. Beperkt de taak van de gevolmachtigde zich tot het afleggen van een verklaring die hem door de volmachtgever nauwkeurig is opgegeven, dan moet men letten op wil en kennis van de volmachtgever. ${ }^{7}$ Diverse schrijvers wijzen erop dat de gevolmachtigde in dat laatste geval ook louter bode kan zijn en dat artikel 3:66 lid $2 \mathrm{BW}$ dan toepassing mist. ${ }^{8}$ Van den Brink merkt terecht op dat voor de wederpartij vaak niet kenbaar is hoeveel vrijheid de gevolmachtigde in zijn verhouding tot de volmachtgever toekomt. Vertaald naar termen van de rechtspersoon: de wederpartij zal zijn verwachtingen omtrent hetgeen de volmachtgever weet - welke verwachtingen mede de inhoud van een overeenkomst kunnen bepalen - baseren op de indruk die hij van de gevolmachtigde en eventueel de volmachtgever heeft gekregen over de handelingsvrijheid van de gevolmachtigde. Bij de uitleg van overeenkomsten zal de kennis van de gevolmachtigde in aanmerking moeten worden genomen naar gelang van het aandeel dat de gevolmachtigde kenbaar voor de wederpartij had bij de totstandkoming van de overeenkomst en de bepaling van de inhoud daarvan. ${ }^{9}$ In 2009 oordeelde de Hoge Raad dat het perspectief van de wederpartij in belangrijke

6. Vgl. Van Schaick 2011, 41, volgens wie de volmachtgever een 'aandeel' heeft als hij op grond van hetgeen hij wist, aanleiding had en in staat was om het sluiten van de overeenkomst te voorkomen, maar het bewust heeft nagelaten.

7. PG Boek 3, p. 274

8. Tjittes 2001, p. 15, voetnoot 19; Asser/Van der Grinten \& Kortmann 2-I 2004/80; Van Schaick 2011, 41.

9. V. van den Brink, Vertegenwoordiging en de inhoud van de overeenkomst, in: W.E. Haak (red.), WB der Nederlanden, Nijmegen: Wolf Legal Publishers 2003, p. 110. Zo ook A-G Langemeijer in zijn conclusie voor HR 11 november 2005, NJ 2007/231 (Ontvanger/Voorsluijs), nr. 2.14 en Valk 2012, p. 766. De beide laatsten verwijzen naar HR 27 januari 1989, NJ 1989/816 (Van den Berg en Van Gestel/Hendriks). In lijn daarmee (t.a.v. een pseudo-gevolmachtigde): Hof Leeuwarden 30 mei 2001, NJ 2001/677 (Amev/Roggen), r.o. 7. 
mate bepaalt of een makelaar geacht mocht worden gevolmachtigde te zijn - en dus met een zekere vrijheid naar eigen oordeel kon handelen - in plaats van slechts bode. ${ }^{10}$ Volgens Valk moet het aandeel van de gevolmachtigde in het algemeen worden beoordeeld vanuit het gerechtvaardigd perspectief van de wederpartij. ${ }^{11}$ A-G Langemeijer gaat er in zijn conclusie voor het arrest Ontvanger/Voorsluijs eveneens van uit dat het perspectief van de wederpartij die met de vertegenwoordiger heeft onderhandeld en de daaruit voortvloeiende verwachtingen van de wederpartij doorgaans bepalen wie het grootste aandeel in de totstandkoming had. ${ }^{12} \mathrm{Ik}$ sluit mij aan bij deze visie, nu die recht doet aan de regels over de rechtsverhouding tussen contractspartijen, maar ik zie in elk geval twee uitzonderingen. De eerste is het geval waarin een volmachtgever de relevante kennis bezit, maar een onwetende gevolmachtigde naar voren schuift die bij de wederpartij de indruk wekt een grote handelingsvrijheid te hebben. $\mathrm{Na}$ ontdekking daarvan zal de wederpartij zich mijns inziens mogen beroepen op de kennis van de volmachtgever. De tweede uitzondering betreft de gevallen waarin de kennis aan de zijde van de volmachtgever relevant is voor de verhouding tot een ander dan de contractuele wederpartij, zoals bij de actio pauliana. Voor de vraag of de schuldeiser wetenschap van benadeling had, is irrelevant welke indruk daarover bestond bij de schuldenaar.

\section{Welk type kennis?}

Bij de beoordeling van wilsgebreken zoals dwaling is niet alleen relevant welke feiten de dwalende kende, maar ook hoe deskundig hij was. Naar de letter is artikel 3:66 lid 2 BW buiten het gebied van wilsvorming en wilsgebreken alleen van toepassing op feitenkennis. Met Tjittes en Van Schaick ga ik er echter van uit dat de leer van het grootste aandeel mede de deskundigheid van volmachtgever en gevolmachtigde bestrijkt. ${ }^{13}$ Deskundigheid speelt in allerlei andere situaties dan die van wilsgebreken dezelfde rol als feitenkennis. Denk aan de uitleg van een overeenkomst: hoe een partij een bepaalde term in een overeenkomst mag opvatten, kan zowel afhangen van zijn kennis van bepaalde feiten als van zijn deskundigheid. ${ }^{14}$ Het zou ongerijmd zijn als de volmachtgever zich in zo'n geval wel de feitenkennis van zijn gevolmachtigde zou moeten laten toerekenen, maar niet diens deskundigheid. Bovendien is de grens tussen feitenkennis en deskundigheid niet altijd duidelijk: als iemand vaker reproducties van antieke kasten heeft bestudeerd, heeft hij dan feitelijke kennis van kenmerken van eerdere reproducties of is hij deskundig ten aanzien van reproducties van antieke kasten?

\footnotetext{
10. HR 26 juni 2009, NJ 2010/664 (Wiggers/Makelaardij Sneek).

11. Valk 2012, p. 766.

12. Conclusie voor HR 11 november 2005, NJ 2007/231, par. 2.14.

13. Tjittes 2001, p. 14: ('vakkennis') en Van Schaick 2011, 41, p. 57 ('ervaring' ).

14. Vgl. HR 17 december 1976, NJ 1977/241 (Bunde/Erckens).
}

De tekst van artikel 3:66 lid 2 BW maakt geen onderscheid tussen subjectieve en objectieve kennis. Niettemin oordeelde de Rechtbank Utrecht in 2012: 'het uitgangspunt (...) dat in het algemeen bij volmacht de subjectieve bekendheid van de gevolmachtigde toegerekend kan worden aan de volmachtgever (...) is onjuist'. ${ }^{15}$ Volgens de rechtbank is toerekening van subjectieve wetenschap in beginsel niet verenigbaar 'met de betekenis van subjectiviteit in de zin van behorend tot één individu of het gevolg van inwendige, niet voor anderen waarneembare oorzaken'. Het geval waarover de rechtbank oordeelde, betrof een vrouw die haar huisarts verweet dat hij een TIA bij haar niet had opgemerkt toen zij hem bezocht met klachten. Een maand na haar bezoek aan de huisarts kreeg de vrouw een herseninfarct, gevolgd door een locked-in syndroom. Haar echtgenoot schreef enkele maanden later een brief aan de huisarts waarin hij aangaf dat het gezin van huisarts veranderde omdat het de huisarts verweet de TIA niet te hebben opgemerkt. Negen jaar later stelde de vrouw de huisarts aansprakelijk. De huisarts beriep zich op verjaring onder verwijzing naar voornoemde brief. Volgens de rechtbank kon toerekening van subjectieve wetenschap van de vertegenwoordiger aan de vertegenwoordigde alleen plaatsvinden in het geval van wettelijke vertegenwoordiging. De rechtbank baseerde dit oordeel op de strekking van de korte verjaringstermijn van artikel 3:310 lid 1 BW en het arrest Saelman/VU, ${ }^{16}$ waarin de Hoge Raad oordeelde dat die verjaringstermijn pas begint te lopen zodra de benadeelde of diens wettelijk vertegenwoordiger voldoende zekerheid heeft gekregen dat het letsel (mede) is veroorzaakt door tekortschietend of foutief medisch handelen. Hieruit leidt de rechtbank af dat voor toerekening van de subjectieve kennis van een vertegenwoordiger slechts plaats is in gevallen waarin een individu niet in staat kan worden geacht subjectieve wetenschap te verkrijgen dan wel te verwerken, althans zijn belangen te behartigen, en voor wie de wetgever het instituut van wettelijke vertegenwoordiging in het leven heeft geroepen.

Naar mijn idee plaatst de rechtbank deze zaak ten onrechte in de sleutel van de volmacht. Het gaat in deze zaak niet om de vraag of subjectieve kennis van een gevolmachtigde toerekenbaar is aan de volmachtgever - artikel 3:66 lid 2 BW laat daar geen twijfel over bestaan -, maar om de vraag of hier wel sprake was van een door een gevolmachtigde verrichte rechtshandeling. De echtgenoot trad mogelijk op als gevolmachtigde van zijn vrouw bij de opzegging van de contractuele relatie met de huisarts, maar die opzegging was geen aansprakelijkstelling. De korte verjaringstermijn van artikel 3:310 lid $1 \mathrm{BW}$ start op het moment dat de benadeelde bekend rakt met de schade en de aansprakelijke persoon. Het 'bekend raken met' is geen rechtshandeling en het staat allerminst vast dat artikel 3:66 lid 2 BW kan worden toegepast op de start van een verjaringstermijn.

15. Rb. Utrecht 30 mei 2012, NJF 2012/323.

16. HR 31 oktober 2003, NJ 2006/112; zie r.o. 4.20 van de rechtbank, zoals kenbaar uit het in NJ gepubliceerde arrest. 
Zolang niet vaststond dat de echtgenoot al bij het schrijven van de brief optrad als gevolmachtigde van zijn vrouw voor het te gelde maken van de vordering wegens tekortschietend medisch handelen, is toerekening van de kennis van de echtgenoot aan zijn vrouw - of dit nu objectieve of subjectieve kennis is - op grond van artikel 3:66 lid $2 \mathrm{BW}$ niet aan de orde. In die context is goed te verdedigen dat in een geval als het onderhavige de kennis van het ene individu slechts aan de ander wordt toegerekend wanneer die ander niet in staat kan worden geacht subjectieve wetenschap te verkrijgen of te verwerken, althans zijn belangen te behartigen en die ander om die reden een wettelijke vertegenwoordiger heeft. In zoverre kan ik meegaan in het oordeel van de rechtbank.

\section{De rechtspersoon als volmachtgever}

Artikel 3:66 lid 2 BW veronderstelt dat de volmachtgever zelf kennis en een wil heeft. Hoe moeten wij dat zien wanneer de volmachtgever een rechtspersoon is? Mijns inziens zal bij de toepassing van de leer van het grootste aandeel acht moeten worden geslagen op het individu dat namens de rechtspersoon de volmacht heeft verstrekt. Dit kan een bestuurder zijn, maar ook een andere functionaris binnen de organisatie, zoals een afdelingshoofd. ${ }^{17}$ Die zal doorgaans zelf ook over een volmacht beschikken, zodat sprake is van ondervolmacht en diens kennis als 'kennis van de gevolmachtigde' kan worden toegerekend. Zie daarover paragraaf 5 hierna. Is het individu dat de volmacht feitelijk verstrekt een wettelijk of statutair vertegenwoordiger van de rechtspersoon (bestuurder, procuratiehouder) en dus niet ook zelf gevolmachtigde, dan geldt zijn kennis als die van de volmachtgever in de zin van artikel 3:66 lid $2 \mathrm{BW} .{ }^{18} \mathrm{Het}$ feit dat niet dat individu, maar de rechtspersoon juridisch gezien de volmachtgever is, doet hieraan naar mijn mening niet af. In de parlementaire geschiedenis van artikel 3:66 lid 2 BW is nu eenmaal geen bijzondere aandacht besteed aan het feit dat de volmachtgever/vertegenwoordigde vaak een rechtspersoon is, terwijl een wettelijk of statutair vertegenwoordiger door de wet of statuten is aangewezen om de wil van de rechtspersoon te vormen en het handelen van een dergelijk individu (in die hoedanigheid) geldt als het handelen van de rechtspersoon zelf. ${ }^{19}$

Veel rechtshandelingen worden voor de rechtspersoon verricht door functionarissen aan wie niet expliciet een

17. In dat geval is sprake van ondervolmacht, art. 3:64 BW. Zie daarover par. 5 hierna.

18. Zo ook: Asser/Van der Grinten \& Maeijer 2-II 1997/107 (stelt kennis van bestuur gelijk aan kennis van volmachtgever in de zin van art. 3:66 lid 2 BW).

19. Hetzij op grond van de wet (art. 2:45 (vereniging), 2:53a jo. 2:45 (coöperatie en onderlinge waarborgmaatschappij), 2:130 (naamloze vennootschap), 2: 240 (besloten vennootschap) en 2:292 (stichting) BW), hetzij op grond van hetgeen in het maatschappelijk verkeer heeft te gelden (HR 6 april 1979, NJ 1980/34, Kleuterschool Babbel). volmacht is verstrekt voor het verrichten van een bepaalde rechtshandeling. De vertegenwoordigingsbevoegdheid ligt vaak besloten in de aanstelling van de functionaris en is dan stilzwijgend verleend (art. 3:61 lid $1 \mathrm{BW}$ ) of neergelegd in de functieomschrijving in de arbeidsovereenkomst of overeenkomst van opdracht. ${ }^{20}$ De caissière is bevoegd om namens de rechtspersoonsupermarkt bepaalde koopovereenkomsten aan te gaan; de general counsel is bevoegd om zelfstandig de advocaat van de vennootschap te instrueren. De verlener van dergelijke aanstellingsvolmachten - doorgaans een bestuurder of het hoofd personeelszaken met volmacht van het bestuur - zal vaak geen aandeel hebben in de totstandkoming van de rechtshandeling. Hij zal soms niet eens meer bij de rechtspersoon werkzaam zijn op het moment dat de rechtshandeling wordt verricht. Bij gebrek aan een aandeel van de verlener van de volmacht in de totstandkoming van de rechtshandeling is er dan dus geen grond of aanleiding om diens kennis aan de rechtspersoon toe te rekenen.

De kennis van andere functionarissen dan degene die de volmacht feitelijk verstrekt, kan niet op grond van artikel 3:66 lid 2 BW aan de rechtspersoon worden toegerekend. Toerekening kan in voorkomende gevallen overigens wel plaatsvinden op andere gronden, maar dan zal - anders dan bij artikel 3:66 lid2 BW - een weging moeten plaatsvinden van alle omstandigheden van het geval.

\section{Meerdere gevolmachtigden en ondervolmacht}

In het geval van ondervolmacht verleent de gevolmachtigde de hem verleende volmacht aan een ander (art. 3:64 BW). Bij grotere organisaties zullen ondervolmachten vaak voorkomen: een functionaris krijgt dan een volmacht van zijn leidinggevende in plaats van van het bestuur. Die leidinggevende ontleent zijn bevoegdheid op zijn beurt aan een (impliciete) volmacht van het bestuur. Ik zie geen reden waarom artikel 3:66 lid 2 BW niet (analoog) zou kunnen worden toegepast in geval van ondervolmacht. De kennis van iedere (onder)gevolmachtigde komt in aanmerking naar gelang van zijn aandeel in de totstandkoming van de rechtshandeling en de bepaling van haar inhoud. ${ }^{21}$

Een voorbeeld van een toepassing hiervan biedt een arrest van het Hof Amsterdam uit 1998. ${ }^{22}$ Randstad Uitzendbureau B.V. had het faillissement aangevraagd van Hello Magazine B.V. Een dag voor de zitting waarbij die aanvraag zou worden behandeld, kwamen beide partijen

20. Vgl. Handboek voor de NV en de BV 2013, p. 507

21. Van Schaick $(2011,22)$ merkt op dat art. 3:66 lid 2 in dit geval betrekking heeft op de volmachtgever en de substituut-gevolmachtigde. Dat zal zo zijn indien de 'hoofd'gevolmachtigde met de totstandkoming van de rechtshandeling geen bemoeienis heeft. Heeft die echter ook een aandeel in de rechtshandeling, dan zal zijn kennis evenzeer worden toegerekend.

22. Hof Amsterdam 8 februari 1996, NJ 1998/265 (Randstad/Rosenberg Polak q.q.). 
via hun advocaten overeen dat Randstad genoegen zou nemen met betaling van een deel van haar vordering. $\mathrm{Na}$ betaling zou de faillissementsaanvraag worden ingetrokken. Tijdens de zitting, waar Randstad werd vertegenwoordigd door een kantoorgenoot van haar procureur, ${ }^{23}$ bleek dat meerdere partijen het faillissement van Hello Magazine hadden aangevraagd. De aanvragen werden aangehouden. Randstad ontving vervolgens de overeengekomen betaling, maar korte tijd later werd een van de andere verzoeken tot faillietverklaring toegewezen. De curator vernietigde de betaling op grond van artikel 47 Faillissementswet $\left(\mathrm{F}_{\mathrm{w}}\right)$, volgens welk artikel de voldoening door de schuldenaar van een opeisbare schuld kan worden vernietigd indien de ontvanger van de betaling op het moment van ontvangst wist dat het faillissement van de schuldenaar was aangevraagd. Randstad ontkende deze wetenschap te hebben. Volgens het hof moest de wetenschap van Randstads procesvertegenwoordiger gelden als wetenschap van Randstad zelf, omdat hij Randstad bij de zitting vertegenwoordigde. Zonder dit artikel uitdrukkelijk te noemen, past het hof dus artikel 3:66 lid $2 \mathrm{BW}$ toe. $\mathrm{Nu}$ is dit oordeel wel inpasbaar in de systematiek van artikel 3:66 lid $2 \mathrm{BW}$, maar dat vergt wat uitleg: de vernietigde rechtshandeling is immers de betaling aan Randstad, en het is niet evident dat de kantoorgenoot van Randstads procureur in de totstandkoming daarvan een aandeel had. ${ }^{24}$ Randstads procesvertegenwoordiger was gevolmachtigd tot het instemmen met het aanhouden van de zitting. Zou een beoordeling van déze rechtshandeling voorliggen, dan zou Randstad in het kader daarvan op grond van artikel 3:66 lid $2 \mathrm{BW}$ zonder meer geacht worden te weten dat er meerdere faillissementsaanvragen aanhangig waren. De rechtshandeling die ter beoordeling voorlag - omdat zij door de curator was vernietigd -, was echter een andere, namelijk de ontvangst van de betaling. In díe rechtshandeling had Randstads procesvertegenwoordiger geen aandeel. Op grond van artikel 3:66 lid 2 BW geldt de kennis die een gevolmachtigde opdoet bij het verrichten van de ene rechtshandeling niet tevens als kennis van de volmachtgever in het kader van een andere rechtshandeling, indien deze gevolmachtigde in die andere rechtshandeling geen aandeel heeft. Van Schaick lijkt te veronderstellen dat de procesvertegenwoordiger het in zijn macht had om de betaling aan Randstad te voorkomen en lijkt dat te zien als een aandeel in de ontvangst. ${ }^{25}$ Dat is een mogelijke uitleg, al wordt de ingrijpmacht van de kantoorgenoot van de procureur daarbij wellicht overschat. Ik geef er de voorkeur aan om in een geval als dit, waarin zo'n nauw verband bestaat tussen het aanhouden van de faillissementsaanvraag en het ontvangen van de beta-

23. Tot 1 september 2008 konden procespartijen zich in rechte slechts laten vertegenwoordigen door een advocaat die ingeschreven was op het tableau van het arrondissement waar het gerecht was gevestigd. Speelde de zaak in een ander arrondissement, dan schakelde de behandelend advocaat een procureur in: een advocaat in het toepasselijke arrondissement, die vrijwel geen inhoudelijke bemoeienis had met de zaak.

24. Het hof noemt art. 3:66 lid 2 BW ook niet; Van Schaick $(2011,41)$ ziet dit arrest wel als een toepassing van dat artikellid. Dat lijkt ook te gelden voor Asser/Van der Grinten \& Kortmann 2-I 2004/81.

25. Van Schaick 2011, 41 ling, het begrip rechtshandeling wat minder beperkt op te vatten. De redenering is dan als volgt. De procesvertegenwoordiger van Randstad ter zitting was een ondergevolmachtigde van de advocaat die de betalingsregeling trof (art. 3:64 BW). Ik neem aan dat de volmacht aan de advocaat ook de afwikkeling van de betalingsregeling omvatte, waaronder het instemmen met aanhouding en het intrekken van de faillissementsaanvraag. Door een procureur opdracht te geven naar de zitting te gaan en hem de vrije hand te laten om zijn kantoorgenoot af te vaardigen, heeft de advocaat van Randstad ervoor gekozen om de mogelijkheid om kennis te nemen van belangrijke ontwikkelingen voor rechtshandelingen waartoe hij gevolmachtigd was, over te laten aan een ander. Met andere woorden: de ondergevolmachtigde had een aandeel in de totstandkoming van de betaling door ter zitting in te stemmen met aanhouding. De 'rechtshandeling' in de zin van artikel 3:66 lid 2 BW bestond dan dus uit het aangaan en afwikkelen van de betalingsregeling. Deze benadering is meer in lijn met de overwegingen van het hof en vergemakkelijkt ook de toepassing van artikel 3:66 lid $2 \mathrm{BW}$ in andere gevallen. Veelal zal de opdracht aan een gevolmachtigde immers het tot stand brengen van een bepaald rechtsgevolg inhouden en niet zozeer het verrichten van een specifieke rechtshandeling. Voor het bereiken van het rechtsgevolg kunnen meerdere rechtshandelingen nodig zijn waaraan meerdere personen een bijdrage leveren.

Wanneer een volmachtgever twee gevolmachtigden inschakelt om een rechtshandeling tot stand te brengen en de overeenkomst door beiden dient te worden ondertekend, is geen sprake van ondervolmacht, maar van meerdere gevolmachtigden. De kennis van hen beiden kan zonder meer in aanmerking worden genomen naargelang hun aandeel. Vaak zullen echter meerdere individuen met een algemene (aanstellings)volmacht binnen een rechtspersoon samenwerken bij de totstandkoming van een overeenkomst, zonder dat een handtekening van beiden nodig is. De vraag is of zij hun werkzaamheden dan verrichten in hun hoedanigheid van gevolmachtigde. Artikel 3:66 lid $2 \mathrm{BW}$ ziet op het individu dat namens de volmachtgever de rechtshandeling verricht. Is vanaf het begin duidelijk wie de overeenkomst namens de rechtspersoon zal ondertekenen, dan zou men kunnen betogen dat de overigen niet gelden als gevolmachtigden in de zin van artikel 3:66 lid 2 BW en dat hun kennis dus ook niet op grond van dat artikel in aanmerking hoeft te worden genomen. Dat lijkt mij een ongewenst enge uitleg van dat artikellid. Steun voor een ruimere uitleg vind ik in jurisprudentie en literatuur.

In het arrest Engelvaart/Brusselsche Bank (1930) oordeelde de Hoge Raad over een geval waarin een klant van een bank wegens bedrog de nietigheid inriep van een overeenkomst tot koop van aandelen. Volgens de klant had de hoofdinspecteur van de bank hem voorgelogen over de waarde van de aandelen. De aandelen waren aan de klant verkocht door een andere, kennelijk onwetende gevolmachtigde. Voor de Hoge Raad volstond niet dat de hoofdinspecteur de aandelen had aangeprezen; vereist was dat diezelfde gevolmachtigde de 
volmachtgever had vertegenwoordigd bij 'het voorbereiden of afsluiten der overeenkomsten' ${ }^{26}$ Dit impliceert dat voor toerekening van kennis volstaat dat de gevolmachtigde de rechtshandeling heeft voorbereid. Een verdere eis (het mede-sluiten van de overeenkomst) werd niet gesteld. Wel vatte de Hoge Raad 'voorbereiden' vrij beperkt op: het aanprijzen viel daar niet onder.

Meijers uitte in zijn noot onder het arrest kritiek op deze beslissing: volgens hem leidt het standpunt van de Hoge Raad ertoe dat bij een rechtspersoon een contract onaantastbaar wordt, ook al is het door bedrog tot stand gekomen, mits maar het bedrog door een andere vertegenwoordiger gepleegd wordt dan degene die het contract namens de rechtspersoon sluit. Volgens Meijers mag het er 'slechts op aan[komen] of [de wederpartij] degene die het bedrog pleegt met de vertegenwoordigde mag identificeeren. Dit mag hij doen van het oogenblik, dat de bedrieger in zijn functie van vertegenwoordiger, d.w.z. bij de vervulling van de hem opgedragen taak, het bedrog pleegt.' Dit kan een reden zijn om het 'aandeel' in de totstandkoming van de rechtshandeling bij functionarissen van een rechtspersoon ruim op te vatten.

Van der Grinten en Kortmann achten voldoende dat 'het handelen van hem die het bedrog pleegde - mede tot de overeenkomst heeft geleid'. ${ }^{27}$ Dat is een ruimer en soepeler criterium dan de Hoge Raad hanteerde. Voor de toerekening van wetenschap van benadeling in het kader van de actio pauliana (art. 3:45 BW) eisen Van der Grinten en Kortmann dat de collega die niet de paulianeuze koop sloot een 'substantieel aandeel' in de totstandkoming van de overeenkomst had. Dat lijkt een strengere eis dan bij bedrog. Een reden voor het verschil wordt niet gegeven. Op basis van het type kennis dat door de relevante norm wordt vereist, zou men het eerder andersom verwachten: een beroep op bedrog kan pas slagen wanneer de wederpartij subjectieve kennis (opzet) heeft, terwijl de actio pauliana al kan worden ingeroepen wanneer de wederpartij van de schuldenaar behoorde te weten van de benadeling. Je zou dan verwachten dat aan de betrokkenheid van de 'wetende maar niet handelende' gevolmachtigde hogere eisen worden gesteld bij een beroep op bedrog dan bij de actio pauliana.

Bij dit alles komt wel de vraag op hoe relevant het nu eigenlijk is dat de functionaris die de overeenkomst mede voorbereidt, over een volmacht beschikt. In de praktijk hoeft het aandeel in de totstandkoming van de overeenkomst van een functionaris zonder volmacht niet onder te doen voor dat van een functionaris met volmacht. Beiden kunnen dezelfde rol spelen in onderhandelingen. In een dergelijk geval kan naar mijn mening

26. HR 28 februari 1930, NJ 1930, p. 1258 e.v., i.h.b. p. 1262 (Engelvaart/ Brusselsche Bank). Het oud BW kende geen equivalent van art. 3:66 lid 2 BW, maar ook vóór 1992 werd kennis van de gevolmachtigde toegerekend aan de volmachtgever.

27. Asser/Van der Grinten \& Kortmann 2-I 2004/81 artikel 3:66 lid 2 BW analoog worden toegepast of geldt een aan artikel 3:66 lid $2 \mathrm{BW}$ verwante regel. ${ }^{28}$

\section{Rechtsverhouding tussen volmachtgever en een ander dan zijn wederpartij}

Een door een gevolmachtigde verrichte rechtshandeling zal doorgaans slechts invloed hebben op de rechtspositie van de volmachtgever en diens wederpartij. Die rechtshandeling en de daarvoor relevante kennis kunnen echter ook gevolgen hebben voor de rechtspositie van derden. Voor de revindicerende eigenaar is van belang of de verkrijger ten tijde van de overdracht door de nietbeschikkingsbevoegde bezitter te goeder trouw was (art. 3:86 en 3:88 $\mathrm{BW}$ ); voor de curator is van belang of de wederpartij van de schuldenaar wetenschap had van benadeling (art. $42 \mathrm{Fw}$ ); bij het onrechtmatig profiteren van wanprestatie is voor de gelaedeerde van belang of de laedens wist dat zijn wederpartij wanprestatie jegens de gelaedeerde pleegde. Ten aanzien van de actio pauliana staat buiten kijf dat de kennis van de gevolmachtigde ook dan aan de volmachtgever wordt toegerekend ${ }^{29}$ en ik zie niet in waarom dat voor de andere genoemde gevallen anders zou zijn. De tekst van artikel 3:66 lid 2 BW wijst niet op het tegendeel. Steun hiervoor vind ik daarnaast bij Tjittes. ${ }^{30}$

Bij de toepassing van artikel 3:66 lid 2 BW in de rechtsverhouding tussen de volmachtgever en een derde geldt wat mij betreft echter wel een duidelijke grens. De kennis van de gevolmachtigde kan slechts in aanmerking worden genomen wanneer de rechtshandeling die door die gevolmachtigde is verricht ter beoordeling voorligt: was de volmachtgever te goeder trouw bij de overdracht van de zaak, had de volmachtgever wetenschap van benadeling bij het aangaan van de koopovereenkomst? De door de gevolmachtigde verrichte rechtshandeling kan relevant zijn in de rechtsverhouding tussen de volmachtgever en een derde, maar dat betekent niet dat de kennis van de gevolmachtigde op grond van artikel 3:66 lid $2 \mathrm{BW}$ ook moet worden toegerekend aan de volmachtgever wanneer een andere rechtshandeling ter beoordeling voorligt. De vraag welke rechtsverhouding ter beoordeling voorligt, wordt bij de toepassing van artikel 3:66 lid 2 BW niet altijd scherp in acht genomen. Illustratief daarvoor is het arrest Dijkstra/Batstra. ${ }^{31}$ Daarin sprak de koper van een verzakkend huis de verkoper aan tot schadevergoeding. De aannemer van de verkoper had, ondanks een verplichting daartoe in de bouwvergunning, geen

28. Zie voor een uitgebreide onderbouwing van deze stelling B.M. Katan Toerekening van kennis aan rechtspersonen: een vuistregel voor 'standaardgevallen', WPNR (2014) 7039, p. 1081-1087.

29. Zie Hof Amsterdam 8 februari 1996, NJ 1998/265 (Randstad/Rosenberg Polak q.q.) en de behandeling daarvan in par. 5 hiervoor en zie HR 2 januari 1930, NJ 1930, p. 1254 e.v. (Van Dijk/Bankassociatie).

30. Tjittes 2001, p. 14.

31. HR 11 februari 2000, NJ 2000/294 (Dijkstra/Batstra), r.o. 3.6 
overleg gevoerd met de gemeente over de wijze van fundering. Volgens het hof kwam het niet-voeren van overleg voor rekening van de verkoper en had de verkoper aldus het gebrek in de fundering behoren te kennen: 'een door de aannemer, de gevolmachtigde, binnen de grenzen van zijn volmacht verrichte rechtshandeling - i.c. overleg met de gemeente - [treft] hem, als volmachtgever, in haar gevolgen'. Volgens de Hoge Raad mocht deze objectieve kennis (het 'behoren te weten') van de aannemer niet aan de verkoper worden toegerekend op de voet van artikel 3:66 lid 2 BW. Hij motiveerde dit als volgt:

'Het voeren van overleg door een aannemer met de gemeente over de eisen waaraan een bouwwerk moet voldoen, [kan] niet worden aangemerkt als een door de aannemer verrichte rechtshandeling. De resultaten van het overleg kunnen dan ook niet op grond van volmacht aan Dijkstra als volmachtgever worden toegerekend.' 32

$\mathrm{Nu}$ overleg geen rechtshandeling is, had het hof de kennis van de aannemer niet op grond van volmacht (art. 3:66 lid $2 \mathrm{BW}$ ) mogen toerekenen. Om het arrest van het hof te kunnen vernietigen was niet méér nodig dan deze constatering. Maar ook als de aannemer wel een rechtshandeling had verricht, had zijn kennis niet aan de verkoper mogen worden toegerekend. Stel dat de aannemer namens de verkoper een overeenkomst met de gemeente had gesloten. In de rechtsverhouding tussen de verkoper en de gemeente zou de kennis van de aannemer dan zijn toegerekend aan de verkoper. Het is echter bepaald niet evident dat die kennis ook aan de verkoper wordt toegerekend in de verhouding tussen de verkoper en de koper van het huis. Bij de totstandkoming van de koopovereenkomst en de bepaling van de inhoud daarvan was de aannemer immers niet betrokken. Stel nu dat de verkoper de aannemer tijdens de bezichtiging uitgebreid overleg had laten voeren met de koper over bouwtechnische details. Het zou mij niet verbazen indien de Hoge Raad in dat geval wel zou toestaan dat de objectieve kennis van de aannemer aan de verkoper wordt toegerekend, al dan niet bij wijze van analoge toepassing van artikel 3:66 lid $2 \mathrm{BW} .{ }^{33}$ Niet het karakter van de handelingen die de annemer verrichtte acht ik uiteindelijk doorslaggevend, maar de rechtsverhouding waarbinnen de aannemer optrad. ${ }^{34}$

Artikel 3:66 lid 2 BW zegt iets over de gevolgen van de rechtshandeling die door de gevolmachtigde is verricht. Het regelt niet welke kennis een volmachtgever in het algemeen geacht wordt te hebben. De kennis van de gevolmachtigde wordt niet toegerekend aan de volmachtgever in de zin dat de volmachtgever wordt geacht

32. R.o. 3.6.

33. Vgl. HR 27 januari 1989, NJ 1989/816 (Van den Berg en Van Gestel/ Hendriks), waarin de Hoge Raad volgens Valk ( 2012, p. 766-767) art. 3:66 lid 2 BW analoog leek toe te passen. Zie over de toelaatbaarheid van analoge toepassing van art. 3:66 lid 2 BW HR 11 november 2005, NJ 2007/231 (Ontvanger/Voorsluijs), r.o. 3.8.

34. Zie over de toerekening van kennis buiten rechtshandelingen Katan 2014, p. 1081-1087. ook in de toekomst steeds met die kennis te opereren. De kennis van de gevolmachtigde geldt niet zonder meer als kennis van de volmachtgever bij de beoordeling van een latere rechtshandeling die een andere gevolmachtigde namens dezelfde volmachtgever verricht. Toepassing van artikel 3:66 lid $2 \mathrm{BW}$ op andere, latere rechtshandelingen zou ertoe leiden dat de kennis in acht moet worden genomen van iemand die in het geheel geen aandeel heeft gehad in de totstandkoming van de (latere) overeenkomst. Daarvoor biedt artikel 3:66 lid 2 BW naar mijn mening geen basis.

Het zal overigens niet altijd gemakkelijk zijn om te beoordelen wat nog wel of niet meer kan worden gerekend tot de rechtshandeling waarin de gevolmachtigde een aandeel heeft. In rechtspraak over de actio pauliana is geregeld aan de orde of de diverse rechtshandelingen kunnen worden gezien als een samenstel dat in zijn geheel beschouwd de crediteuren heeft benadeeld. ${ }^{35}$ Wanneer een gevolmachtigde een aandeel had in een van die samenhangende rechtshandelingen, kan zijn kennis wellicht ook in aanmerking worden genomen bij de overige rechtshandelingen. Een algemene regel over wanneer een samenstel van rechtshandelingen geldt als één rechtshandeling voor de toepassing van artikel 3:66 lid $2 \mathrm{BW}$ valt echter niet te geven, nu dit sterk afhangt van de omstandigheden van het geval.

\section{Andersom: toerekening van kennis van volmachtgever aan gevolmachtigde?}

Artikel 3:66 lid 2 BW regelt de toerekening van de kennis van de gevolmachtigde aan de volmachtgever, niet de toerekening van de kennis van de volmachtgever aan de gevolmachtigde. Wanneer de gevolmachtigde echter een eigenbelang heeft bij de totstandkoming van de rechtshandeling, wordt in de rechtspraak soms aangenomen dat de kennis van de volmachtgever kan worden toegerekend an de gevolmachtigde, al dan niet onder verwijzing naar artikel 3:66 lid $2 \mathrm{BW}$.

Dat gebeurde bijvoorbeeld in de uitspraak van de Rechtbank Den Haag in de zaak die leidde tot het arrest ING Bank/Van Leuveren q.q. ${ }^{36}$ In die zaak trad de gevolmachtigde niet alleen op namens de volmachtgever, maar was zij tevens diens wederpartij. De kredietnemer, tevens pandgever, had een algemene volmacht verstrekt aan de bank om de vorderingen van de pandgever op derden aan de bank te verpanden. De bank liet dagelijks een verzamelpandakte registreren waarin zij namens al haar pand- en volmachtgevers hun vorderingen op derden aan zichzelf verpandde. De pand-/volmachtgever vroeg zijn eigen faillissement aan. Dat werd een kleine week later uitgesproken. De curator stelde dat

35. Zie Wessels Insolventierecht III 2013/3054-3056, ook voor verwijzingen naar jurisprudentie en literatuur.

36. HR 1 februari 2013, NJ 2013/156. 
de kennis van de pand-/volmachtgever over de eigen faillissementsaanvraag op grond van artikel 3:66 lid 2 BW moest worden toegerekend aan de bank als gevolmachtigde. Nu de bank tevens pandhouder was, meende de curator dat hij de verpandingen ${ }^{37}$ op grond van artikel 47 Fw kon vernietigen. Volgens de rechtbank kon aan ING als gevolmachtigde de kennis van de volmachtgever worden toegerekend, maar niet ook aan ING als mederpartij van de volmachtgever. De 'eerste poot' van dat oordeel, dus dat aan de gevolmachtigde de kennis van de volmachtgever kan worden toegerekend, acht ik onjuist.

Artikel 3:66 lid $2 \mathrm{BW}$ geeft aan welke kennis voor risico komt van de volmachtgever - de totstandkoming en gevolgen van de door de gevolmachtigde verrichte rechtshandeling komen immers op grond van artikel 3:66 lid $1 \mathrm{BW}$ voor zijn rekening. Artikel 3:66 lid 2 BW rekent om die reden de kennis van de gevolmachtigde toe aan de volmachtgever. Het biedt echter geen ruimte voor toerekening in omgekeerde richting, dat wil zeggen van de volmachtgever aan de gevolmachtigde. A-G Timmerman overwoog mijns inziens dan ook terecht dat artikel 3:66 lid 2 BW niet op deze situatie ziet (conclusie, nr. 3.84). De Hoge Raad liet zich over artikel 3:66 lid $2 \mathrm{BW}$ in het geheel niet uit.

Ook de Rechtbank Oost-Nederland rekende in een vonnis van 23 januari 2013 ten onrechte de kennis van de volmachtgever toe aan de gevolmachtigde. ${ }^{38}$ In die zaak fungeerde CAK als doorgeefluik voor voorschotten die zorgverzekeraar Menzis verstrekte aan een thuiszorgorganisatie. Op enig moment betaalde de thuiszorgorganisatie een te veel ontvangen voorschot terug aan Menzis door overschrijving naar de rekening van CAK. Enkele dagen later failleerde de thuiszorgorganisatie. De rechtbank stelde vast dat Menzis wetenschap van benadeling had op het moment van de overschrijving. De curatoren vorderden het overgeschreven bedrag terug van CAK. De rechtbank stelt vast dat CAK de betaling 'namens Menzis' had ontvangen. 'Daaruit volgt' aldus de rechtbank, dat de wetenschap van Menzis aan CAK moest worden toegerekend. Maar dat volgt daar helemaal niet uit. ${ }^{39}$

Kan kennis van de volmachtgever dan nooit aan de gevolmachtigde worden toegerekend? Ik sluit niet uit dat dit in bepaalde, uitzonderlijke omstandigheden wel zal kunnen, maar niet op grond van artikel 3:66 lid 2 BW. Dergelijke omstandigheden worden in de hiervoor behandelde uitspraken bovendien niet genoemd.

\section{Slot}

Veel aspecten van de toerekening van de kennis van de gevolmachtigde aan de volmachtgever zijn tot op heden onderbelicht gebleven. In dit artikel heb ik een aantal van die aspecten onder de loep genomen. Dit leidt tot de volgende conclusies:

1. Onder 'aandeel' moet in de leer van het grootste aandeel worden verstaan: een reële mogelijkheid om te voorkomen dat de rechtshandeling wordt verricht überhaupt of onder deze voorwaarden.

2. Deskundigheid kan op grond van artikel 3:66 lid 2 BW ook aan de volmachtgever worden toegerekend buiten het gebied van wilsgebreken.

3. Bij een rechtspersoon geldt de kennis van de persoon die feitelijk de volmacht heeft verstrekt als kennis van de volmachtgever indien die persoon een wettelijk of statutair vertegenwoordiger is; verstrekken andere leidinggevenden een volmacht, dan zal doorgaans sprake zijn van ondervolmacht.

4. In geval van ondervolmacht en van meerdere gevolmachtigden kan de kennis van iedere (onder)gevolmachtigde in de keten aan de volmachtgever worden toegerekend al naar gelang zijn aandeel in de totstandkoming van de rechtshandeling of de bepaling van haar inhoud.

5. Is de rechtshandeling die de gevolmachtigde heeft verricht onderwerp van geschil tussen de volmachtgever en een ander dan zijn wederpartij bij die rechtshandeling, dan is artikel 3:66 lid 2 BW 'gewoon' van toepassing: de kennis van de gevolmachtigde geldt ook in de relatie tussen volmachtgever en derde als kennis van de volmachtgever. Ligt echter een ándere rechtshandeling ter beoordeling voor, dan kan artikel 3:66 lid 2 BW niet worden toegepast.

6. Anders dan in de lagere rechtspraak soms wordt verondersteld, biedt artikel 3:66 lid 2 BW geen grond voor toerekening van kennis van de volmachtgever aan de gevolmachtigde.
37. Dit zouden logischerwijs moeten zijn: de verpandingen die plaatsvonden na de faillissementsaanvraag. De curator ging echter voor meerdere ankers liggen en riep ook de vernietiging in van eerdere verpandingen.

38. Rb. Oost-Nederland 23 januari 2013, JOR 2014/76 (curatoren Stichting Thuiszorg Groningen/ Menzis en CAK).

39. Ter zijde: de rechtbank had de eventuele verplichting tot terugbetaling überhaupt niet mogen baseren op de actio pauliana: CAK was immers slechts doorgeefluik en geen schuldeiser. 